\title{
AN OVERVIEW OF THE DEVELOPMENT OF THE OIL PALM INDUSTRY AND IMPACT OF THE SHELL GENE INNOVATION AS A QUALITY CONTROL TOOL TO IMPROVE PRODUCTIVITY
}

\author{
SINGH, R $^{\star *}$; LEE, K T*; OOI, L C L*; LOW, E T L*; ABDULLAH, M O*; \\ SAMBANTHAMURTHI, $\mathbf{R}^{\star}$ and AZMAN, ${ }^{\star \star *}$
}

\begin{abstract}
The oil palm, from West Africa, has greatly contributed to the economy of Malaysia, especially in raising the living standards of the rural population. The crop has also helped satisfy the growing need for oils and fats by the ever-increasing world population. Nevertheless, the palm oil industry is now at the cross-roads, facing serious challenges in its declining yield brought on by issues such as climate change, shortage of labour and arable land. Modern biotechnology, which can differentiate between high performing and low performing palms in the nursery prior to field planting can help in addressing some of these challenges, especially by improving the crop's productivity. This article relates the historical development of the industry in Malaysia, its contribution to the country's economy and explores how science and technology are necessary for its long-term sustainable development. In line with this, a simple economic model demonstrates the feasibility of applying DNA testing to reduce low yielding non-tenera contamination in commercial fields.
\end{abstract}

Keywords: biotechnology, oil palm, shell gene.

Received: 10 July 2020; Accepted: 11 October 2020; Published online: 7 January 2021.

\section{INTRODUCTION}

The history of oil palm in South East Asia harkens back to 1848 when the Dutch brought four seedlings from West Africa to the Bogor Botanical Gardens, Indonesia. They were brought in as ornamentals and not for agriculture (Hunger, 1924; Jagoe 1952). Interestingly, the first oil palm in Malaysia (then Malaya, where Singapore was considered part of Malaya) were those sourced by the Singapore Botanic Gardens in the 1870s from the Royal Botanic

\footnotetext{
Malaysian Palm Oil Board,

6 Persiaran Institusi, Bandar Baru Bangi,

43000 Kajang, Selangor, Malaysia.

E-mail: azman@mpob.gov.my

** Business School, Sunway University,

5 Jalan Universiti, Bandar Sunway,

47500 Selangor, Malaysia.

\# Contributed equally to the article.
}

Garden in Kew, England (Kushairi et al., 2017). It was not until 1917 that the economic potential of the crop was realised in Malaysia, when Frenchman, Henri Fauconnier, planted the first commercial stand at Tennamaram Estate in Batang Berjuntai, now township Bestari Jaya, Selangor, using seeds from the four Bogor palms in Indonesia (Fauconnier, 1948; Kushairi et al., 2017).

The declining price of rubber, then the major crop in the country, saw the oil palm industry gain momentum in the early 1930s, although there was a hiatus in its expansion in the Second World War (Kushairi et al., 2017). However, from the 1960s the industry took off with the area increasing more than 100-fold from a mere 55000 ha to 5.74 million hectares in 2016 (Nambiappan et al., 2018). The climate in South East Asia (particularly in Malaysia and Indonesia) - having sufficient rainfall which is evenly distributed and good sunshine - is ideal for the crop which produces more than double its yield in its African homeland. 


\section{HIGH PRODUCTIVITY AND DEMAND FOR EDIBLE OILS FUEL GROWTH OF THE OIL PALM INDUSTRY}

Malaysia's attempt to diversify its agriculture (from mainly rubber) in the 1960s was behind the rapid growth of the oil palm industry (Basiron, 2007). Its expansion was aided by the replanting of rubber and other crops with oil palm, as it was considered an extremely profitable crop with oil yield of up to 10 times those of other competing vegetable oil crops (like soyabean and rapeseed) per unit land area (Nambiappan et al., 2018). This inherent high productivity is the reason why palm oil now accounts for approximately one third of the oils and fats produced worldwide (Kushairi et al., 2019), despite being planted on merely $5 \%$ of the total area dedicated to the production of vegetable edible oils. In fact, being the most productive vegetable oil crop, makes oil palm the ideal choice to meet the increasing demand for oils and fats by the ever-expanding world population, which is expected to exceed 9 billion by 2050 (Béné et al., 2015). The projected rise in the living standards and income of the growing population is also expected to fuel additional requirement for palm oil, as an increase in affluence raises the demand for oils and fats in the daily diet (Murphy, 2014). This is already being observed in some major palm oil importing countries like India, where vegetable oil consumption per capita rose by $>90 \%$ due to rising income (Murphy, 2007). In fact, Tzachor (2019) predicts that by 2030 a significant proportion of the population ( $\sim 4.9$ billion) will be categorised as middle class, with substantial change in dietary habits, which will likely include increase in the consumption of oils and fats. Currently, Malaysia and Indonesia together account for $85 \%$ of the world production of palm oil, making South East Asia the most important region in the world to meet the growing demand for edible oils and fats (Alam et al., 2015).

\section{Contribution of Oil Palm to Malaysia's Economic and Social Development}

As a developing country, Malaysia sought to improve the economic life of its rural population and agriculture was seen as a key means to this end. For example, resettlement schemes such as the Federal Land Development Authority (Felda) were established as projects to grant land and farming jobs to the landless poor who were living below the poverty level. The establishment of resettlement schemes was in part also fuelled by the World Bank which saw the potential in Malaysia's agriculture sector to uplift the living standard of rural families (Takata, 2008). The first resettlement schemes planted rubber, but with its falling prices in the 1980s (Barlow, 1997), subsequent schemes relied more heavily on oil palm. The shift from rubber to oil palm demonstrated dynamism in the economic viability and sustainability of replanting schemes, which successfully transformed poor rural agriculturebased settlements into near-urban like towns, with much improved amenities (Barau and Said, 2016). The progressiveness of the resettlement schemes was also evident when by the end of the 1980s opening of new schemes was halted (Sutton, 1989), inadvertently contributing to sustainability practices. Today, smallholders, many in Felda schemes, account for almost $40 \%$ of the oil palm area in the country (Alam et al., 2015) and rely on the crop for their daily livelihood. Cultivation of oil palm by the different sectors in Malaysia is shown in Table 1.

TABLE 1. MALAYSIAN OIL PALM AREA (\%) BY SECTORS

\begin{tabular}{cccccc}
\hline Sector & $\mathbf{2 0 0 7}$ & $\mathbf{2 0 1 4}$ & $\mathbf{2 0 1 7}$ & $\mathbf{2 0 1 8}$ & $\mathbf{2 0 1 9}$ \\
\hline $\begin{array}{c}\text { Private } \\
\text { plantations/ }\end{array}$ & 60.3 & 61.5 & 61.0 & 61.0 & 61.1 \\
$\begin{array}{c}\text { Estates } \\
\begin{array}{c}\text { Government } \\
\text { schemes }\end{array}\end{array}$ & 21.4 & 17.4 & 16.1 & 16.4 & 16.6 \\
$\begin{array}{c}\text { (Felda, Risda, } \\
\text { Felcra) }\end{array}$ & 11.0 & 15.0 & 16.9 & 16.8 & 16.7 \\
$\begin{array}{c}\text { Independent } \\
\text { smallholders* }\end{array}$ & & & & & \\
$\begin{array}{c}\text { State schemes/ } \\
\text { Government } \\
\text { agencies }\end{array}$ & 7.3 & 6.1 & 6.0 & 5.8 & 5.6 \\
\hline Total & $\mathbf{1 0 0 . 0}$ & $\mathbf{1 0 0 . 0}$ & $\mathbf{1 0 0 . 0}$ & $\mathbf{1 0 0 . 0}$ & $\mathbf{1 0 0}$ \\
\hline
\end{tabular}

Note: * Independent smallholders were one of the fastest growing sectors in the industry until 2017.

Felda - Federal Land Development Authority;

RISDA - Rubber Industry Smallholders Development Authority; Felcra - Federal Land Consolidation and Rehabilitation Authority.

Source: Ab Rahman et al. (2008); MPOB (2019); (2020).

The economic success of oil palm in raising the living standards of the rural population is seen in the fact that it contributes $5 \%-7 \%$ to the country's Gross Domestic Product (GDP) (Nambiappan et al., 2018). It is also an important source of employment with over 570000 employed directly in the industry (Shukoor et al., 2018). With exports of palm oil and its related products exceeding RM60 billion in 2018 (MPOB, 2019), the crop is also a major foreign exchange earner for the country. Despite the occasional hiccups from its low price and low yield due to the weather and 
other reasons, export earnings from palm oil and its products have been generally consistent as indicated in Figure 1. In fact, the average annual revenue from palm oil and its products over the last six years has been approximately RM66.98 billion (Figure 1), a major source of income to the country. The success of the industry lies on the fact that palm oil is highly valued not only as a food, but also has non-food applications, especially in oleochemicals (Parveez et al., 2015; Chang et al., 2015). More recently, palm oil has also gained popularity in the European Union (EU) as a feedstock for biodiesel (Ivancic and Koh, 2016).

\section{Commercial Cultivation of Oil Palm - A Breakthrough in the Belgian Congo Lays the Foundation for Improved Yields}

The oil palm that is commercially cultivated today is the tenera, which has thin-shell fruit. It is a hybrid from crossing the thick-shell dura and shellless pisifera (Figure 2). The thin shell of the tenera fruit allows it to produce more mesocarp, the oilbearing tissue, and that is why tenera has $30 \%$ more oil than dura (Corley and Lee, 1992). The shell-less pisifera, on the other hand, is usually female sterile, and does not typically produce bunches (Singh et al., 2013a). For this reason, pisifera is usually

Source: MPOB (2020).

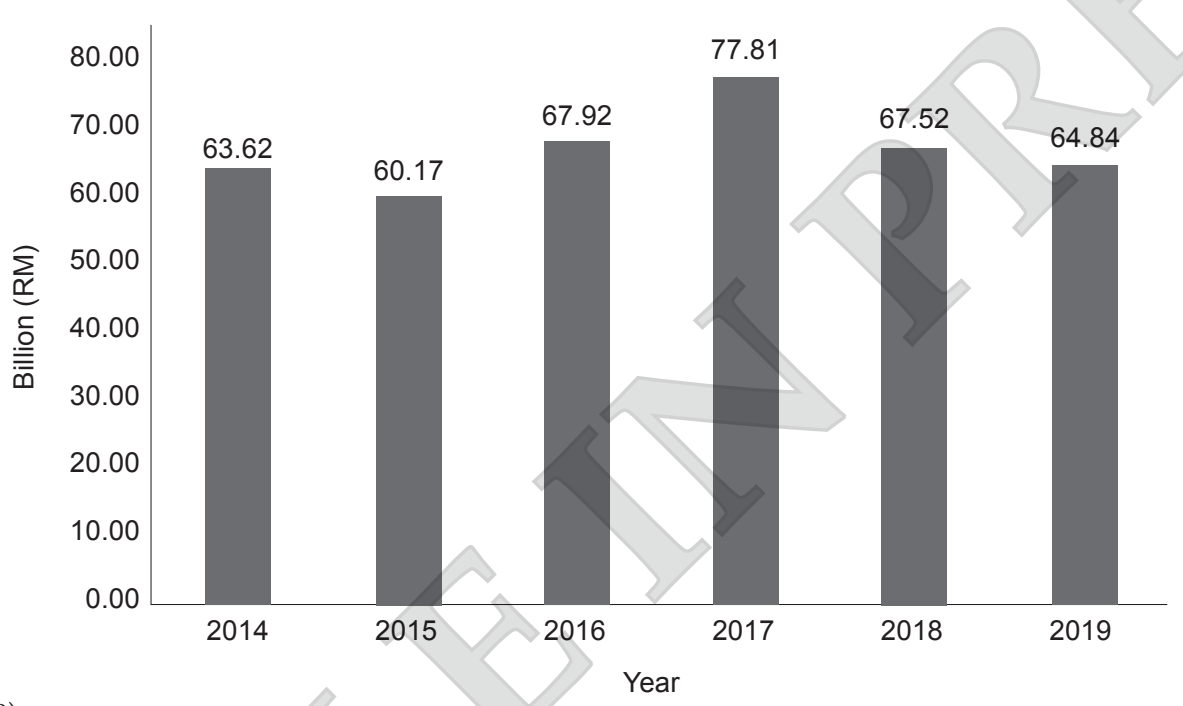

Figure 1. Export earnings from palm oil and its products (2014-2019).

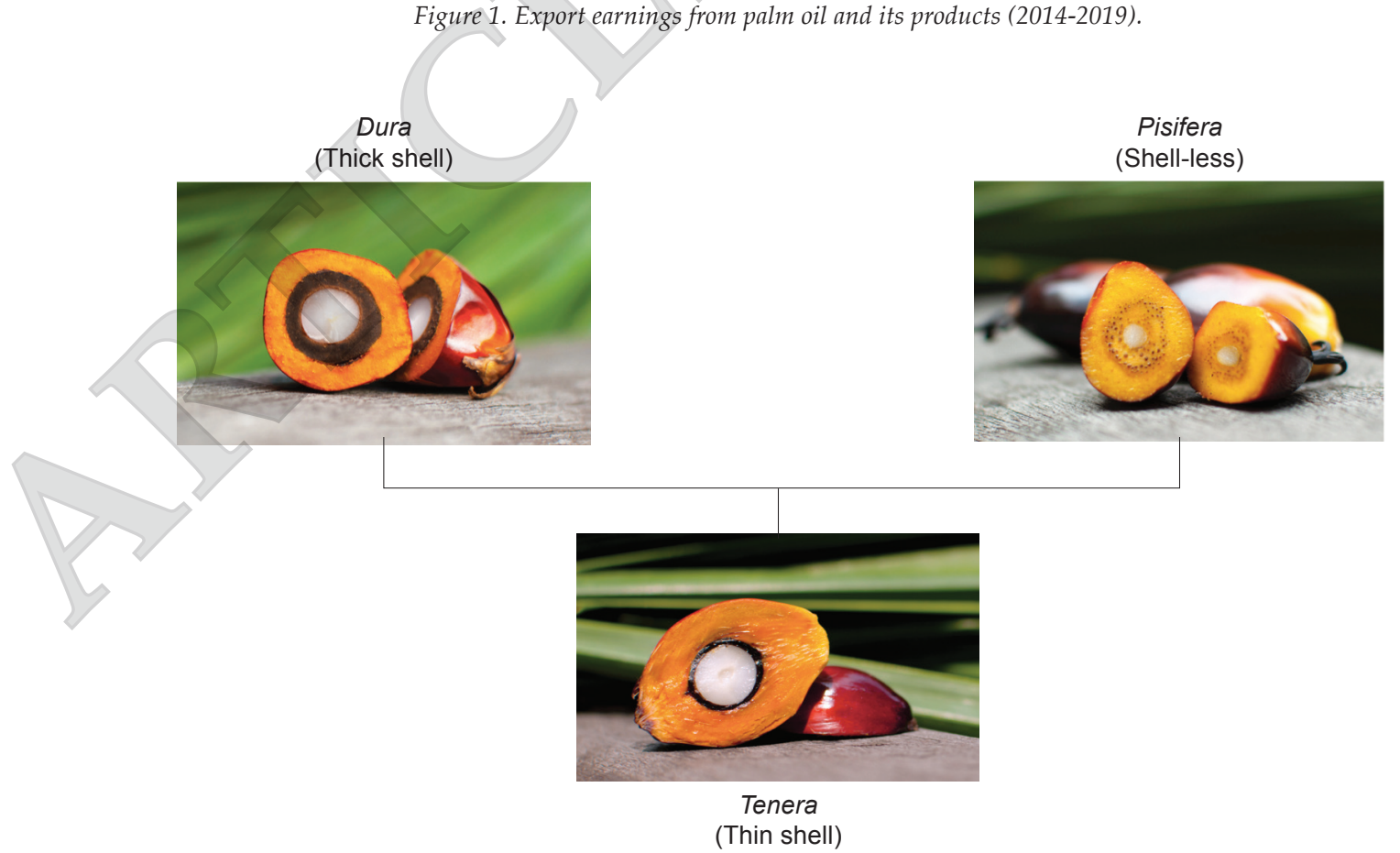

Figure 2. The three fruit forms of oil palm. Tenera is a hybrid of dura and pisifera and due to its thinner shell, has more of the orange fleshy oilbearing mesocarp than dura to produce more oil. Pisifera is normally female sterile and does not usually produce bunches. 
used as the pollen source (male palm) and dura the female parent to produce the hybrid tenera.

The early plantations in Malaysia (up to end of 1950s) cultivated pure populations of dura, where nearly all palms produced fruit, although they had the less desirable thick shell and thin mesocarp. Interestingly, up to this period some plantations also cultivated palms arising from dura $\mathrm{x}$ tenera crosses (Rajanaidu and Jalani, 1994), which gave a mixture of dura and tenera palms. However, this was to change due to a discovery made in the 1940s by two European breeders in the Democratic Republic of Congo (then Belgian Congo). These two breeders established that the oil palm has three fruit forms controlled by variants of a single gene, and that crossing the thick-shell dura and the shell-less pisifera produces palms with the desirable thin-shell tenera trait (Beirnaert and Vanderweyen, 1941). Mostly, the fruit of tenera was smaller than that of dura, less impressive, but with less shell and more mesocarp it actually produced more oil, although it was not established at that time how much more.

This finding was eventually adopted in Malaysian plantations in the 1960s, where the intent from that point forward was to only plant tenera. This was also helped by the fact that the new screw press, then recently introduced to express oil from the palm fruits in the 1950s, was more suited to the thin-shell tenera fruit (Ornelas, 2000). The planting of tenera is considered by many as the 'first wave' of yield improvements that helped the industry gain a strong footing in Malaysia (Davidson, 1993).

Malaysian breeders began to develop and maintain separate female (dura) and male (pisifera) populations. These breeding materials were further improved by selecting within dura $\mathrm{x}$ dura and tenera $\mathrm{x}$ tenera or tenera $\mathrm{x}$ pisifera crosses. Subsequently, selected dura and pisifera lines were crossed with the intention to produce seeds of high performing tenera palms in commercial fields. The breeders were aware that not all of the dura by pisifera crosses were 'acceptable' and as such, progeny testing was carried out to determine potentially good parental pairs. In progeny testing trials the offspring were planted and monitored for yield and other performance traits to determine if the parental pairing was suitable for future seed production. This passion for quality control is one of the reasons why Malaysia became a world leader in oil palm cultivation (Basiron, 2007).

\section{Brief Overview of Oil Palm Commercial Seed Production}

Commercial cultivation of oil palm begins with seed production from selected dura (female) and pisifera (male) lines. Currently, there are approximately 24 licensed seed producers in
Malaysia, who collectively met the requirement for producing 47.7 million seeds on average from 2016-2019 (MPOB, 2019; 2020). The commercial seeds have to meet the Standards and Industrial Research Institute of Malaysia (SIRIM) standard, MS157 (Rao and Chang, 2018) which is updated regularly. Basically, there are known good palms, or even lines, for both male and female parents. The parental palms have also to satisfy MS157, i.e. they must meet or exceed minimum quality to be used. Pollen from the male palm (pisifera) is collected and used to pollinate the female palm (dura). The oil palm flowers are borne in inflorescences, and each female flower successfully pollinated will become a seed. The pollinated inflorescence will ripen into a bunch with about 1500-2000 seeds for palms at 10-15 years old (Corley and Tinker, 2008). The pollination is done under strict controlled conditions (Donough et al., 1993) to prevent contamination by stray pollen.

The bunch, on harvest, is brought to the seed laboratory where the seeds are extracted (fruits stripped from the bunch and the mesocarp removed) and stored in refrigerated conditions (Kelanaputra et al., 2018). When an order for the seeds is received, they are subjected to heat treatment to overcome their natural recalcitrance to germination. The whole process from pollination to germination takes about 24 months (Rao and Chang, 2014) without storage. A seed production facility can process up to 100 bunches per day (depending on its capacity) and all seeds from a particular bunch are tagged and kept separately from seeds of other bunches. As such, considerable effort is spent on managing and tracking all samples in a seed production facility. The germinated seeds are planted in polybags in the nursery for 10-12 months before field planting. The palm will bear its first fruit in three years (Singh et al., 2013a). It is only at this time that it is possible to ascertain the fruit type of the palms and assess any contamination of the seed batch by other fruit forms.

Corley (2005) explained how the pollination process can go wrong, and contamination occurs. Some contamination usually occurs (Rao et al., 1994; Hama-Ali et al., 2015) and is acceptable at a low level. The SIRIM standard allows for up to $5 \%$ contamination, which acts as a quality guide for oil palm seed producers. However, until recently determining the level of contamination was only possible 4-5 years after purchasing the seeds, when the palms in the field had fruited, by which time it was almost impossible to determine which batch of seeds was contaminated. As such, an assay to differentiate the three fruit forms early, before field planting, would be useful to overcome the contamination. This is just lately available and still in its infancy. 


\section{MAJOR RESEARCH AND DEVELOPMENT (R\&D) BREAKTHROUGH BY MPOB}

A major R\&D breakthrough was made by MPOB in 2013, when it decoded the oil palm genome (Singh et al., 2013b), and discovered the 'shell gene' and the genetic mechanism of differentiation between the three fruit forms (Singh et al., 2013a). This discovery allowed MPOB and Orion BioSains Sdn Bhd to develop a simple test to ascertain with near perfect accuracy the fruit form of a palm from its deoxyribonucleic acid (DNA), even from a seed years before its palm fruits (Low et al., 2016; Lakey et al., 2017; Low et al., 2018). Thus, planting materials can be tested before field planting for their fidelity.

With the DNA test, MPOB and its commercial partner surveyed independent smallholders who normally get their planting materials from nurseries (Ooi et al., 2016) for the contamination in their palms. There were earlier reports like, for example, Oberthür et al. (2012) of up to $40 \%$ contamination by typing their mature palms. Ooi et al. (2016) used SHELL DNA testing to assess 57 sites across all Malaysia, sampling >10 000 palms and found $10.9 \%$ contamination, twice the SIRIM standard. Indeed, one nursery sold $>60 \%$ nontenera palms, and 12 sites had $>15 \%$ contaminants, confirming the earlier observation by Oberthür et al. (2012). The results were alarming, as it was generally assumed that the contamination of the past had been contained with sufficient quality control measures (Corley, 2005).

Rao et al. (1994) and Oberthür et al. (2012) estimated that the oil extraction rate (OER) from fresh fruit bunches (FFB) will fall $\sim 0.5 \%$ for every $10 \%$ dura contamination rate. In fact, one of the problems plaguing the Malaysian oil palm industry is its yield stagnation or even decline over the last decade (Figure 3). Although production has increased, this was due to the expansion in area and not by yield, and planting material contamination may be a contributing factor to this (Lakey et al., 2017).

What was clear from Ooi et al. (2016) is that non-tenera contamination can now be assessed readily, from the palm DNA, even from seedlings. More importantly, the study showed that nontenera contamination was an issue in the industry, although the severity across the different sectors has yet to be investigated (Rao, 2016). The next obvious question is that if the non-tenera contamination, observed at $10.9 \%$, is problematic, does the industry need to take action? To answer this question, looking only at the independent smallholder sector (15\% of oil palm planted area), Ooi et al. (2016) did an economic analysis and found that with a $10.9 \%$ contamination, the country suffered substantial economic losses of >RM1 billion annually from lower yields in the sector. This suggests that the use of modern biotechnology techniques, such as DNA testing to remove non-tenera contamination, can improve the overall industry productivity.

\section{Impact of Drop in Productivity}

The importance of having the best planting material, especially for oil palm, is due to its vulnerability to many factors, including weather. In Figure 3, it was obvious that in 2016, oil palm suffered a drop in production due to the El Nino weather phenomenon, which brought a long period of dry and hot weather in South East Asia at the

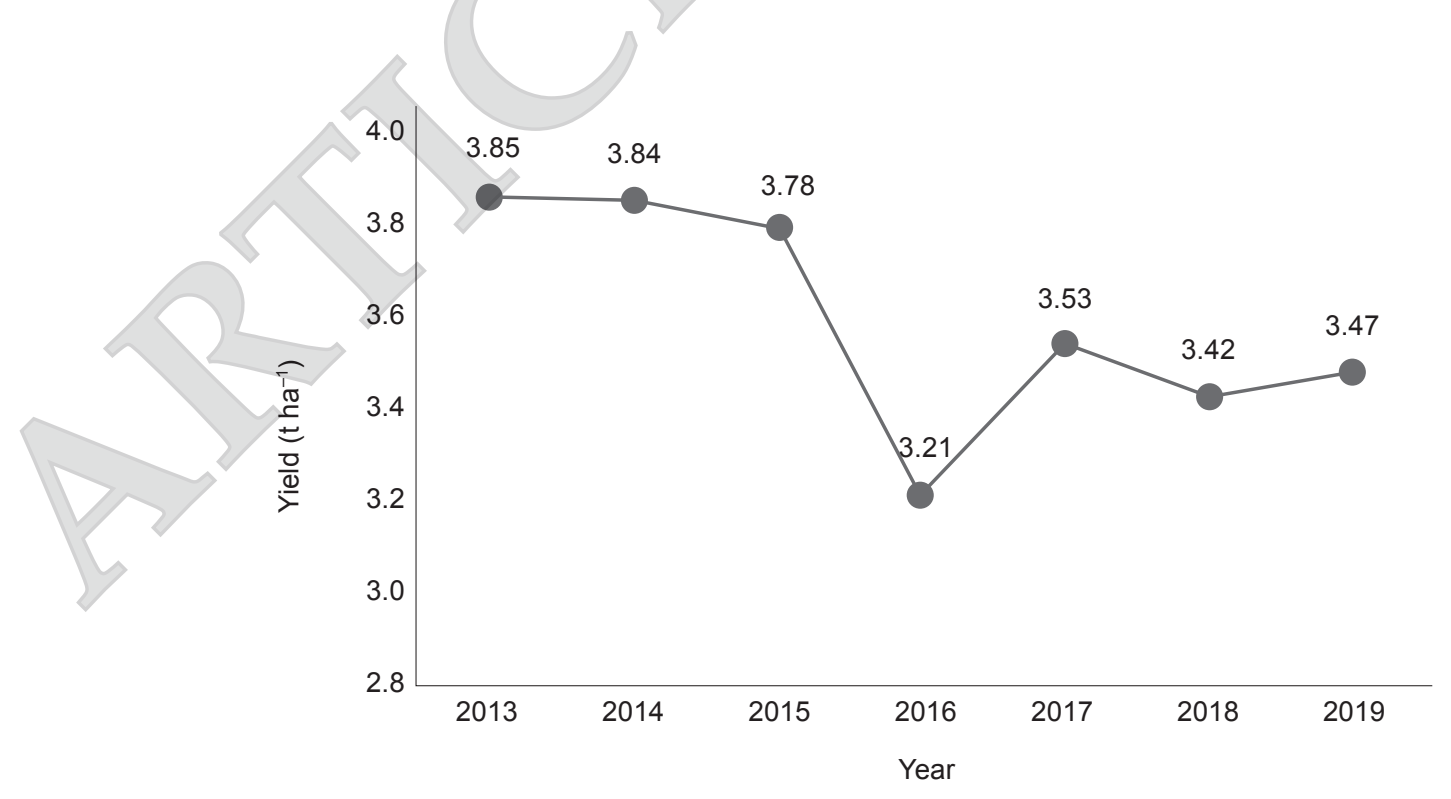

Source: MPOB (2020).

Figure 3. Palm oil yield/ha in Malaysia (2013-2019). A general steady decline is observed and contamination of planting material could be a contributory factor. The sharp decline in 2016 was due to an El Nino that reduced rainfall to stress the palms (Kamil and Omar, 2017). 
end of 2015 and early 2016 (Kamil and Omar, 2017). This resulted in a 13\% drop in crude palm oil (CPO) production in 2016 compared to 2015, causing a shortage with the assumption that demand was unchanged. The supply curve shifted to the left, which resulted in a price increase (Figure 4). CPO prices rose to RM2653 $\mathrm{t}^{-1}$ on average in 2016, an increase of $23 \%$ compared to 2015. Although export revenue for the country saw an increase of $7.3 \%$ (due to the higher CPO price) (MPOB, 2017), this was a temporary gain, as higher $\mathrm{CPO}$ prices result in palm oil being less competitive than other vegetable oils. The vulnerability of the oil palm industry to such factors can be minimised to some extent if biotechnology tools are infused to ensure the best genotypes are identified and planted.

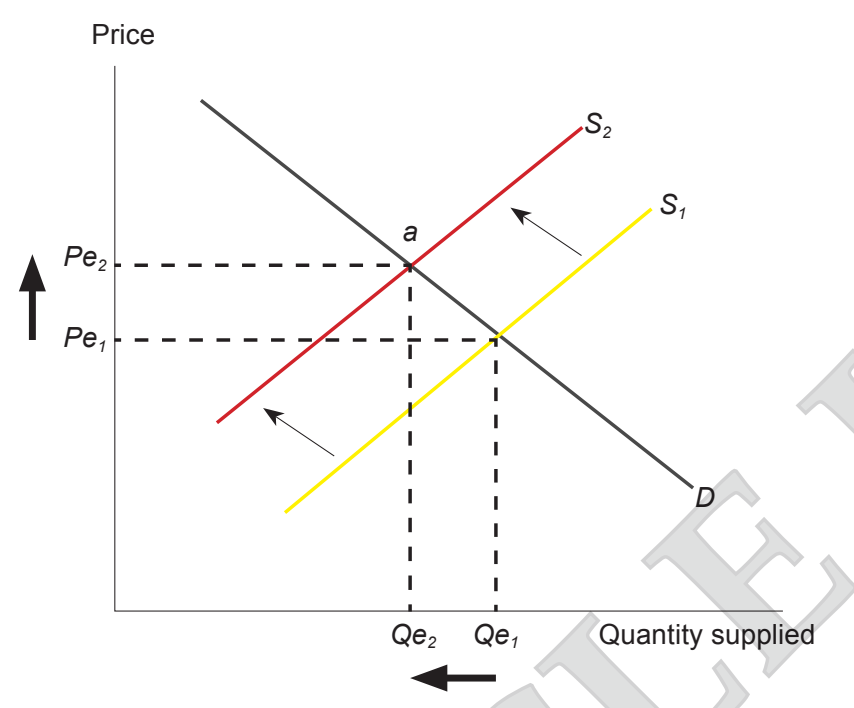

Figure 4. Shortage of palm oil supply in 2016, caused the supply curve $\left(S_{1}\right)$ to shift to the left $\left(S_{2}\right)$. Price increased to $R M 2653 t^{-1}\left(P e_{2}\right)$ from $R M 2153.50\left(P e_{1}\right)$. Quantity supplied dropped from $Q e_{1}$ to $Q e_{2}$, to reach equilibrium at point $a$, with the assumption that demand for palm oil remained unchanged.

\section{Improving Agricultural Productivity with Infusion of Modern Technology}

The year 2008 saw a global food crisis (Lusser et al., 2012) that reinforced the need to use modern biotechnology to innovate agriculture. This is even more necessary when the world population is expected to increase to 9.1 billion by 2050, with the projected food production to increase over $70 \%$ from 2005-2050 to cater to the added demand (Tomlinson, 2013). Innovation in agriculture is even more critical now that the availability of more land to farm is limited. The way to go is either by producing new and improved varieties or selecting the best materials for planting - to give increased yields and be more tolerant to pests and diseases and resilient to climate change.
Broadly, modern biotechnology will be used to produce better plants, either by genetically engineering them or by assisting conventional breeding using DNA diagnostic tools. Genetically engineered crops are gaining popularity with already an estimated $11 \%$ of the world's crops being such (Sandin and Moula, 2015). Some of the major successes are soyabean $(82 \%$ genetically modified $\mathrm{GM})$, cotton (68\% GM), maize (30\% GM) and canola (25\% GM) (James, 2014). However, there remains opposition to GM foods, especially in the European Union and Africa, mainly on the grounds of human health and the environment (Sandin and Moula, 2015). Basically, the opposition stems from a lack of understanding of the technology and this has led to overly stringent requirements for GM products to be released. Recent developments, especially gene editing to hasten genetic gain, appears less controversial. Nevertheless, the European Court of Justice recently ruled that even the products of gene editing would have to go through the same regulatory process as GM crops, which has dampened enthusiasm for the tool (Urnov et al., 2018).

Oil palm is currently GM-free and palm oil products are spared the regulatory burden of genetically modified organisms. This is, at present, an advantage as the industry can focus on other more pressing issues, such as the environmental concerns in its planting. In order to improve oil palm yield and tackle pests and diseases as well as climate change, the focus is to improve current conventional breeding techniques by using DNAbased diagnostic assays (Sambanthamurthi et al., 2009). The assays basically identify in a collection, the individuals / cultivars/varieties that outperform without the need for extensive field trials, saving time and resources in otherwise ponderous efforts to develop new planting materials (Bevan et al., 2017). This does not require genetically modifying the plant, merely selecting the best from the existing natural variation. It is therefore less controversial as it is basically just fine tuning the selection process that humans have been doing for ages.

However, to apply a DNA-based diagnostic assay, several criteria have to be established. The first is that the specific DNA signal linked to the trait being selected for must first have been scientifically established and validated by independent parties. Accuracy of the assay developed from the association of the trait to a DNA signal is the next important requirement especially in applying it in a commercial setting (Vanderzande et al., 2018). Finally, DNA based selection must be economically feasible for it to be viable in large scale application.

In the case of the oil palm SHELL gene, Singh et al. (2013a) clearly showed the association of the trait with a gene, which was validated in many independent studies (Reyes et al., 2015; Babu 
et al., 2017). Subsequently Ooi et al. (2016); Lakey et al. (2017) and more recently Singh et al. (2020) demonstrated the accuracy of the oil palm DNA assay to differentiate dura, tenera and pisifera palms. The economic losses due to the non-tenera palms present in current commercial fields was also predicted by Ooi et al. (2016). However, a simple analysis that shows the gains to be obtained in terms of CPO and palm kernel (PK) yield, if DNA testing is implemented to reduce non-tenera contamination, will be useful in assessing the feasibility of using DNA testing.

\section{Economic Feasibility of Removing Non-tenera Palms Using DNA Assay}

This study used the Malaysian national statistics for oil palm in 2017 (MPOB, 2018) to carry out the analysis. The statistics of 2017 were used in this case study, as the oil palm plantings in 2017 will likely more accurately mimic the contamination rates observed by Ooi et al. (2016). To evaluate gains from DNA testing, we carried out a two-scenario analysis - the first being that the area planted in 2017 had the level of contamination reported by Ooi et al. (2016), that is $8.09 \%$ dura and $1.3 \%$ pisifera. The second scenario was a hypothetical situation, where all the palms planted in 2017 had been tested and the contamination rate was brought down to $0.5 \%$. Another assumption made was that since contamination was reduced to as low as $0.5 \%$ after testing, it was limited to dura, where pisifera contamination was removed altogether from the system, as its levels were much lower to start with. Contamination was kept at $0.5 \%$ dura and not $0 \%$, as it was our opinion that any test implemented in a biological system, for whatever reason, will not achieve zero perfection. The difference in the monetary value of CPO and PK production between the two scenarios reflected the financial losses incurred by the industry due to the contamination of non-tenera planting materials in commercial fields. The industry statistics used for the economics analysis is summarised below:

Total matured area : : 5110713 ha

Total CPO production : 19.9 million tonnes
Total PK production Average CPO price Average PK price

Source: MPOB (2018).

Although the total area planted in 2017 was recorded as 5.8 million hectares (MPOB 2018), the 5.1 million hectares represents the total mature area, consisting of oil palm producing CPO and PK. Table 2 below further summarises the total mature area planted with the three different fruit forms, adjusted for dura and pisifera contamination, and their respective $\mathrm{CPO}$ and $\mathrm{PK}$ yields.

It was presumed that $90.61 \%$ of the area (4.6 million hectares) in 2017 was planted with tenera palms while the remainder with dura $(8.09 \%, 0.4$ million hectares) and pisifera (1.3\%, 0.07 million hectares) palms. Only $98.7 \%$ of the matured area, (minus the 1.3\% pisifera) totalling 5044274 ha produced the 19.9 million tonnes of CPO in 2017. The dura hectarage should have ideally contributed 1.63 million tonnes of the total CPO yield of 2017, based on the matured area without pisifera palms. However, as dura only produces $70 \%$ of the yield observed in tenera palms, the hectarage in actual fact only contributed 1.1 million tonnes, while the remainder 18.8 million tonnes were likely contributed by the area planted with tenera palms. The total CPO yield for the area planted with tenera and dura also allowed the estimation of the yield/ha for both fruit forms, where the difference, as expected, was close to $70 \%$. Total PK yield is usually a quarter of the CPO yield (Van Gelder, 2004).

Based on the above statistics, the CPO and PK produced under the two scenarios outlined above is summarised in Table 3. In the first scenario where palms are planted without testing, the CPO and PK produced in 2017 were almost similar to the official statistics reported (MPOB, 2018). Considering the price for CPO and PK in 2017, the total income was approximately RM68 billion. In the hypothetical scenario where testing was carried out and dura contamination was reduced to $0.5 \%$, the total income generated increased to RM70.6 billion, a gain of approximately RM2.6 billion $\mathrm{yr}^{-1}$. Removing nontenera contamination using the DNA based assay

TABLE 2. THE ESTIMATED CRUDE PALM OIL (CPO) AND PALM KERNEL (PK) YIELD FOR Dura, Tenera AND Pisifera PALMS IN 2017

\begin{tabular}{|c|c|c|c|c|c|c|}
\hline & Rate $(\%)$ & Area (ha) & $\begin{array}{c}\text { CPO yield } \\
\text { (million tonnes) }\end{array}$ & $\begin{array}{c}\text { CPO yield } \\
\text { t ha }^{-1}\end{array}$ & $\begin{array}{c}\text { PK yield } \\
\text { (million tonnes) }\end{array}$ & $\begin{array}{c}\text { PK yield } \\
\text { t ha }^{-1}\end{array}$ \\
\hline Tenera & 90.61 & 4630817 & 18.8 & 4.06 & 4.7 & 1.01 \\
\hline Dura & 8.09 & 413457 & 1.1 & 2.76 & 0.3 & 0.69 \\
\hline Pisifera & 1.3 & 66439 & - & - & - & - \\
\hline Total & 100 & 5110713 & 19.9 & - & 5 & - \\
\hline
\end{tabular}


TABLE 3. SIMPLE ECONOMIC ANALYSIS OF LOSSES SUFFERED BY INDUSTRY DUE TO LOWER CRUDE PALM OIL (CPO) AND PALM KERNEL (PK) PRODUCTION CAUSED BY NON-Tenera CONTAMINATION

\begin{tabular}{|c|c|c|c|}
\hline \multicolumn{2}{|c|}{ Crude palm oil (CPO) } & \multicolumn{2}{|c|}{ Palm kernel (PK) } \\
\hline Actual CPO production in 2017 & 19. 9 million tonnes & Actual PK production in 2017 & 5 million tonnes \\
\hline Estimated CPO from tenera palms & 18. 8 million tonnes & Estimated PK from tenera palms & 4.7 million tonnes \\
\hline Estimated CPO from dura palms & 1.1 million tonnes & Estimated PK from dura palms & 0.3 million tonnes \\
\hline Income 1 (A) & RM55 435498173 & Income $1(\mathrm{C})$ & RM12 556637096 \\
\hline Tenera area after screening & 5085159 ha & Tenera area after screening & 5085159 ha \\
\hline Dura area after screening $(0.5 \%)$ & 25554 ha & Dura area after screening $(0.5 \%)$ & 25554 ha \\
\hline CPO production after screening & 20.7 million tonnes & PK production after screening & 5.14 million tonnes \\
\hline Estimated CPO from tenera palms & 20.6 million tonnes & Estimated PK from tenera palms & 5.13 million tonnes \\
\hline Estimated CPO from dura palms & 0.07 million tonnes & Estimated PK from dura palm & 0.0017 million tonnes \\
\hline Income 2 (B) & RM57 629115586 & Income 2 (D) & RM13 052471527 \\
\hline Estimated loss (A-B) & (RM2 193617 413) & Estimated loss (C-D) & (RM496 834 431) \\
\hline
\end{tabular}

Note: Total gain by removing non-tenera contamination $=$ RM2.69 billion.

increases $\mathrm{CPO}$ and PK production to more than double that estimated by Ooi et al. (2016), which suggests a potentially significant impact on the national economy if implemented by the industry. The increase in profitability will also result in additional tax gains to the Government. The added benefit of DNA testing, is that all agriculture inputs (fertiliser, pest control) are applied on palms that can inherently provide optimal yields. Moving forward, it will be interesting to carry out the analysis by taking into account that the total hectarage consists of palms at different age groups and as such, have varying yield profiles.

DNA and/or protein-based diagnoses are most widely used in medical sciences for the early detection of cancer, especially breast, cervical and colorectal cancer (Molparia et al., 2018; Krieger et al., 2018). DNA-based testing for early detection of cancer or other human diseases is not carried out at present on an entire population, but rather on individuals as recommended by the medical practitioners or by select groups who are aware of and can afford the testing (Foulkes et al., 2016). Although the initial cost of testing and early treatment (if required) can be high (Issa and Noureddine, 2017), the long-term savings to the individual and health care system can be substantial. The use of DNA tests in crops like oil palm has generally lagged human and even animal sciences. Nevertheless, the literature suggests that they are gaining popularity and beginning to be employed widely (Van Nocker and Gardiner, 2014). The most successful application has been in identifying parental lines with certain features (e.g. disease resistance) (Stevanato et al., 2015; Sniezko and Koch, 2017), where the economic justification is obvious. The economic gains appeared dependent on several factors, which include cost of the tests, the number of DNA tests required and severity of culling. Recently Wannemuehler et al. (2019) demonstrated that for a perennial crop like apple, making DNA informed decisions that result in culling or removal of at least $12 \%$ unwanted materials, can substantially improve the economic efficiency of the apple breeding programme. While the cost of DNA testing nationwide to reduce non-tenera contamination has to be determined, improvements in technology are already lowering the cost of DNA-testing (Vanderzande et al., 2018). There is no doubt on the severity of the problem in oil palm as described by Ooi et al. (2016), suggesting that severe culling and with it substantial number of DNA tests will be required. Since the SHELL DNA test is accurate, the problem is large enough, the economic gains are substantial, it collectively suggests that SHELL DNA testing should have good prospects for adoption by the oil palm industry.

\section{Quality Perception of DNA Tested Planting Material}

As the producers of oil palm planting materials also sell their product to other companies and independent nurseries, DNA testing will allow their materials to achieve a higher standard $(99.5 \%$ purity) than the current benchmark set by SIRIM (95\% purity), resulting in quality perception that will exceed customer expectations as shown in Figure 5. If Malaysia takes the lead in implementing DNA testing, the country will establish the bench-mark for quality oil palm planting material globally and help cement Malaysia's role as the world leader in oil palm innovation. 


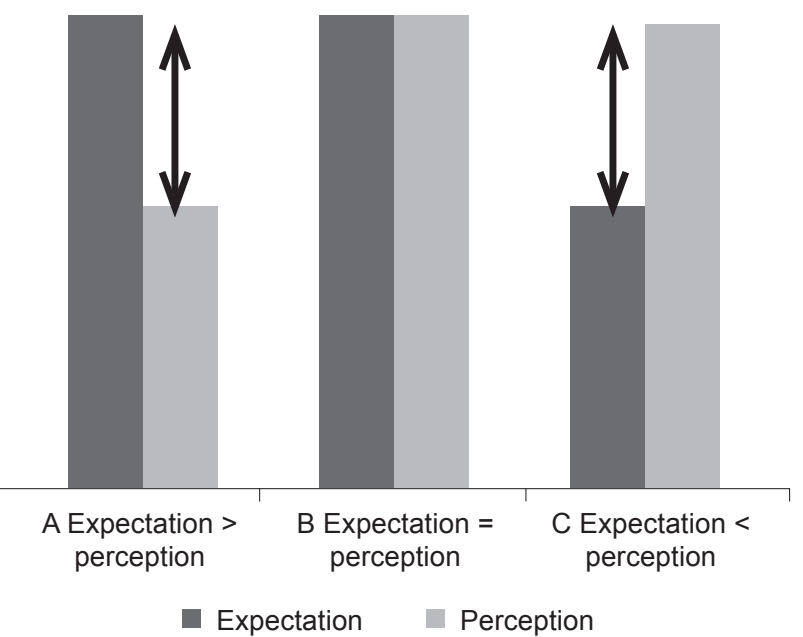

A. Current situation, where non-tenera contamination rates exceed Standards and Industrial Research Institute of Malaysia (SIRIM) standards, customer perception of quality of planting materials is below expectation.

B. Customers perception of planting material, is same as expectation if SIRIM standards of $95 \%$ purity is achieved.

C. If DNA testing implemented, purity of planting materials (99.5\% purity) will exceed SIRIM standards (95\% purity) customer perception of product will exceed expectation.

Adapted from: Slack et al. (2010).

Figure 5. Perceived quality is determined by the gap between customer expectation and perception.

\section{Appropriate Stages to Apply SHELL DNA Testing in Oil Palm}

Selecting the most appropriate stage to implement DNA testing for making informed decisions will influence its successful implementation. Wannemuehler et al. (2020) had demonstrated that incorporating DNA based technology in strawberry was most cost-effective when implemented at the end of seedling trials, instead of at the greenhouse stage. The cost incurred (labour and maintenance) at the greenhouse stage was lower than applying DNA selection at this early stage of strawberry breeding programmes. However, the greenhouse stage was considered the most optimal and cost-effective period to apply DNA based testing in apple, due to its long juvenile phase where the labour and other associated costs are high in conventional programmes, making DNA based selection attractive (Wannemuehler et al., 2019).

Similarly, the cost-effectiveness of testing will be a huge determinant on whether the industry adopts DNA assay for reducing non-tenera contamination. As such, any way to lower the cost without compromising the rigour of testing should be identified/adopted (e.g., using seeds or plantlets instead of field palms) for the DNA analysis. To evaluate the best material to carry out the analysis, it is important to assess the whole process in producing commercial planting materials, as summarised in Figure 6.

Seeds from individual bunches are kept separate until germination. It is only after germination that the seeds from different batches are mixed for sale. Currently, testing at both the seed and nursery stages is technically possible (Lakey et al., 2017; Low et al., 2018), although nursery testing is more convenient due to easier access. A simple analysis (Table 4) demonstrates that testing seeds in the seed production facility is $21 \%$ the cost of testing seedlings in the main nursery. The main reason is that a statistical sample of $10 \%$ of a seed bunch (or a maximum of 100 seeds/bunch) should be sufficient to predict the contamination rate for the bunch (Lakey et al., 2017; Low et al., 2018). In addition, there will be other substantial savings, as contaminated bunches can be rejected before downstream investments are made in the germination, prenursery and main nursery stages. Furthermore, cleaning up the supply chain earlier also has additional benefits - it is easier to trace the source of problem and rectify it.

\section{Adoption of DNA Testing by the Oil Palm Industry}

Economic sustainability requires increase in productivity (yield/ha), lower production costs and stable commodity prices. R\&D has been tailored to reduce production cost (e.g. introduction of mechanisation) and increase yields (improved planting material) in order to minimise the effect of fluctuating commodity prices, that are dictated by the free market and beyond the control of the industry. Although the cost of production for oil palm on a per hectare basis is lower than that of soyabean and rapeseed (Zimmer, 2016), it is rapidly increasing for oil palm, especially due to rise in fertiliser and labour cost (Wahid and Simeh, 2009). The rise in production cost has to be compensated by the increase in CPO and PK yields/ha. This is possible, among other factors through the utilisation of improved planting material, and also by making sure that only the hybrids (DxP or tenera) derived from the selected dura and pisifera parental material are planted. This also ensures that the inputs that contribute to cost of production (e.g. fertiliser) are only supporting palms that have the genetic potential to produce maximum yield. The presence of non-tenera contamination in commercial fields that contributes to significant decline in $\mathrm{CPO}$ and $\mathrm{PK}$ production suggests that there is a strong basis for the industry to adopt DNA based diagnostic assay to remove undesired palms before field planting.

However, an understanding of how the industry is structured may explain why potential adoption of the technology or other DNA based technologies in the future may face some resistance. Currently, 


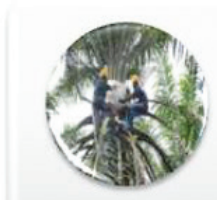

(A)

Pollination

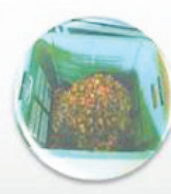

(B)

Individual

bunches

stored in lab

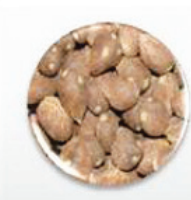

(C)

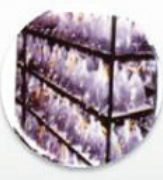

(D)

Seed germination

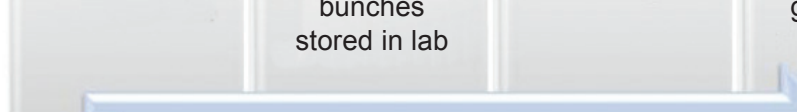

Process flow in the seed production facility

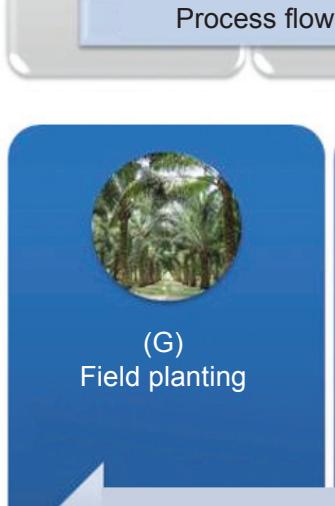

Movement of seeds from pre-nursery to field
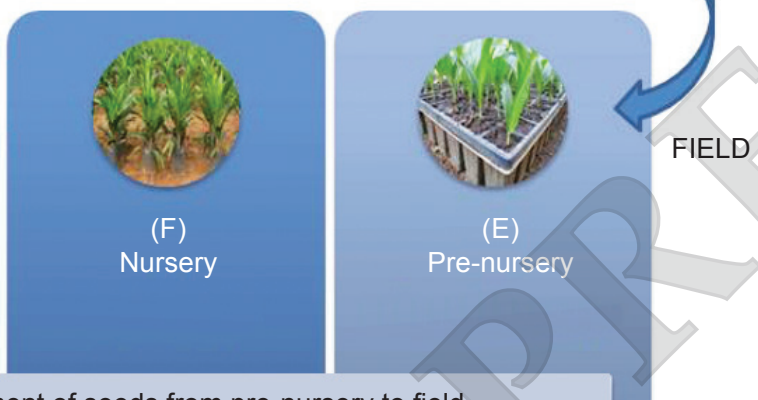

(E)

Pre-nursery

Figure 6. Process flow in commercial oil palm seed production. (A) Pollination; (B) Bunches brought to lab for germination and kept separate; (C) - (D) Upon germination, seeds are individually checked to cull abnormals; (E) - (G) Sowing of germinated seeds in pre-nursery and subsequent movement of seeds from nursery to field. Prior to sowing in the pre-nursery, seeds from the different bunches are kept separate.

TABLE 4. RELATIVE COST ANALYSIS OF SEEDLINGS (in the nursery) OR TESTING SEEDS (at the seed production facility)*

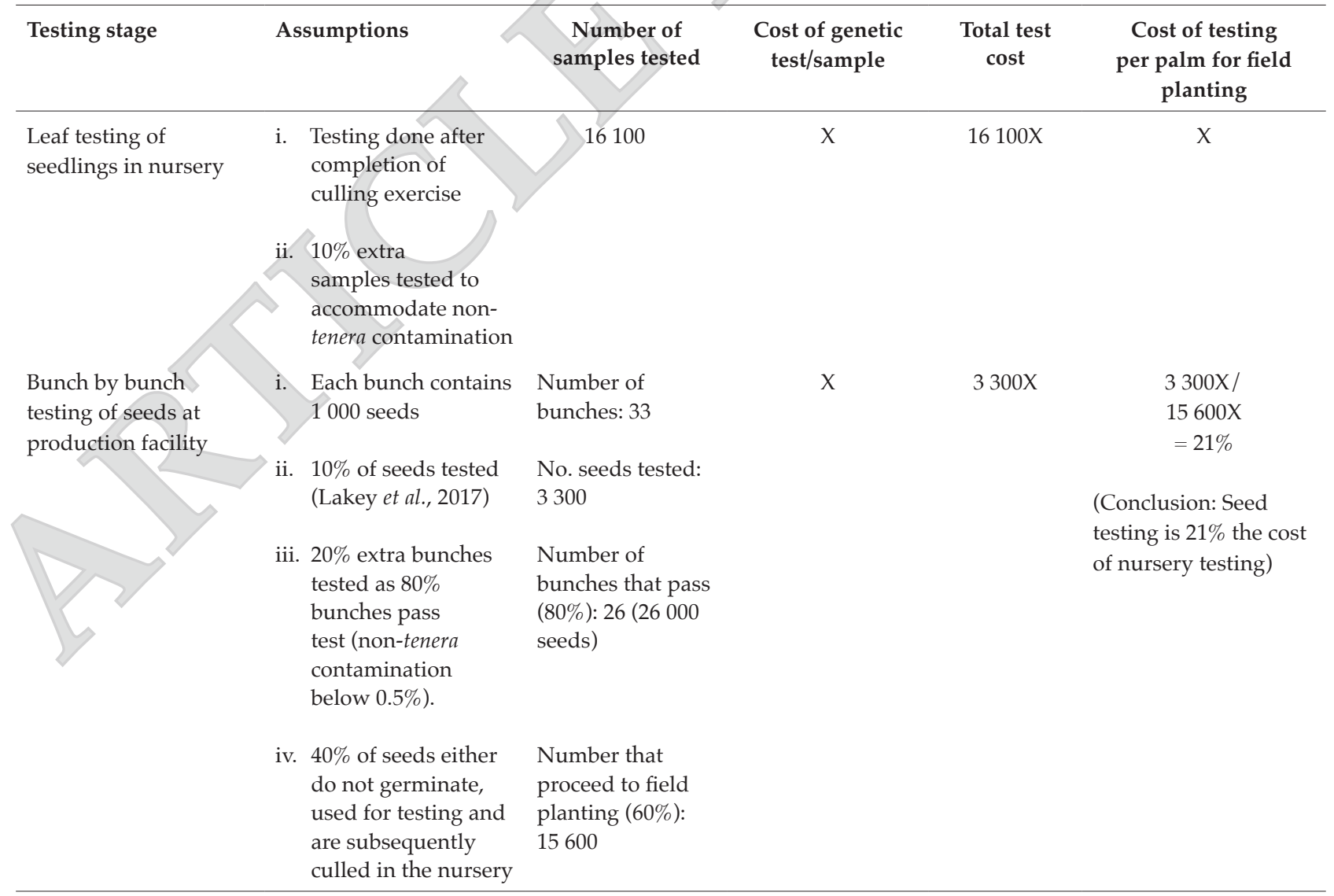

Note: *To provide $\sim 14600$ palms to plant a 100 ha area $\left(146\right.$ palm ha $\left.^{-1}\right)$. 
less than $10 \%$ of the companies engaged in oil palm cultivation in Malaysia are fully integrated, with the relevant upstream (including seed production facility) and downstream activities as illustrated in Figure 7.

If non-tenera contamination is to be removed, the burden will likely fall on the R\&D department, that has to absorb the cost of screening either at the seed production facility or in the nursery, to make sure breeding and commercial fields are free of contamination. However, the benefit of testing will largely be obtained by the downstream sector, which will enjoy higher $\mathrm{CPO}$ and $\mathrm{PK}$ yields from the lower rates of non-tenera contamination. As such, if testing is to be incorporated into the system, commitment is required from higher management for the burden of testing to be shared across all sectors (upstream and downstream) of an integrated company.

Plantation companies that do not have downstream activities, can only accommodate the cost of testing, if mills that accept their FFB are willing to pay the additional cost that guarantees higher $\mathrm{CPO}$ and PK yields. Most impacted are independent smallholders who likely will have to pay more for 'DNA tested planting material', with the hope that their FFB can fetch a higher price in anticipation of higher oil yield. Since these smallholders are small scale producers (in terms of FFB), they do not have the capacity to negotiate with dealers or with mills and have to accept the price offered for their produce. As such, an appropriate industry-wide strategy, that builds a strong commitment to obtain the benefits of DNA testing is required. Without a concerted effort and a commitment to change by all stakeholders, DNA testing at present and in the future (DNA testing for other traits) will not receive the same acceptance as seen in other vegetable oil crops.

\section{CONCLUSION}

Malaysia has been the world leader in oil palm R\&D innovation and together with Indonesia, produces more than $85 \%$ of world palm oil. Malaysia's success has been mostly attributed to its superior field and management practices, apart from the excellent R\&D efforts, which have been shared with other oil palm growing countries. MPOB's ground-breaking research in oil palm genomics, which led to discovery of the shell gene, which is now developed into a DNA diagnostic tool, paves the way for Malaysia to introduce modern biotechnology approaches to improve oil palm productivity. Since the availability of new land for oil palm cultivation in Malaysia is now limited, and, indeed, may even be shrinking from other uses like urbanisation, the only way forward for the industry is to increase its productivity from the existing area. For this, the need for new biotechnology tools is evident as this study revealed that non-tenera contamination (by plants with inferior yields) can be almost two-fold higher than that permissible by SIRIM for oil palm planting materials. As the industry faces serious labour shortage, its quality control in the production of commercial planting materials may be compromised. To arrest the problem, modern biotechnology can be invoked, such as by using the shell gene technology as a quality control tool to ensure the long-term sustainability of the industry. Although the present analysis has clearly demonstrated that adopting DNA testing is financially viable for the industry, the study argues that technological adoption, despite its many benefits, may face resistance from industry. An appropriate industry-wide strategy that facilitates adoption of modern DNA based technologies is thus required.

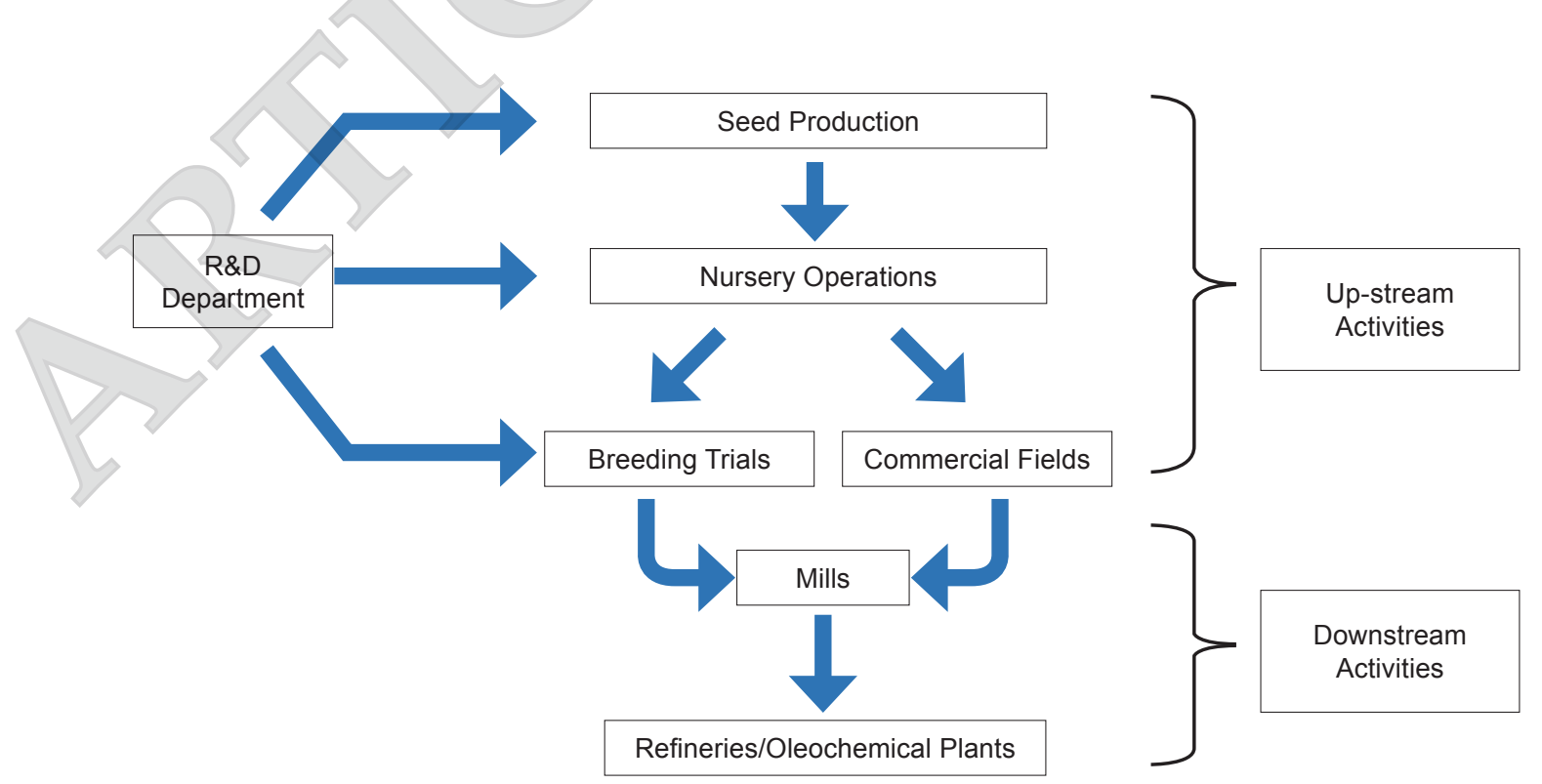

Figure 7. Organisation of upstream and downstream activities in an integrated plantation company. 


\section{ACKNOWLEDGEMENT}

The authors thank the Director-General of MPOB for permission to publish the article. The authors are also grateful to Mr Andy Chang Kwong Choong for his critical comments and edits on the article.

\section{REFERENCES}

Ab Rahman, A K; Abdullah, R; Mohd Shariff, F and Simeh, M A (2008). The Malaysian palm oil supply chain: The role of the independent smallholders. Oil Palm Industry Economic J., 8(2): 17-27.

Alam, A F; Er, A C and Begum, H (2015). Malaysian oil palm industry: Prospect and problem. J. Food, Agriculture and Environment, 13(2): 43-148.

Babu, B K; Mathur R K; Kumar, P N; Ramajayam, D; Ravichandran, G; Venu, M V B and Babu, S S (2017). Development, identification and validation of CAPS marker for SHELL trait which governs dura, pisifera and tenera fruit forms in oil palm (Elaeis guineensis Jacq.). PLOS ONE, 12(2).

Barau, A S and Said, I (2016). From goodwill to good deals: FELDA land resettlement scheme and the ascendancy of the landless poor in Malaysia. Land Use Policy, 54: 423-431.

Barlow, C (1997). Growth, structural change and plantation tree crops: The case of rubber. World Development, 25(10): 1589-1607.

Basiron, Y (2007). Palm oil production through sustainable plantations. European J. Lipid Science and Technology, 109(4): 289-295.

Beirnaert, A and Vanderweyen, R (1941). Contribution a l'etude genetique et biometrique des varieties d'Elaeis guineensis. Jacq. Publs. INEAC, Series Ser. Sci, 27: 101.

Béné, C; Barange, M; Subasinghe, R; PinstrupAndersen, P; Merino, G; Hemre, G I and Williams, M (2015). Feeding 9 billion by 2050-Putting fish back on the menu. Food Security, 7(2): 261-274.

Bevan, M W; Uauy, C; Wulff, B B; Zhou, J; Krasileva, K and Clark, M D (2017). Genomic innovation for crop improvement. Nature, 543(7645): 346-354.

Chang, T S; Yunus, R; Rashid, U; Choong, T S; Biak, D R A and Syam, A M (2015). Palm oil derived trimethylolpropane triesters synthetic lubricants and usage in industrial metalworking fluid. J. Oleo Science, 64(2): 143-151.
Corley, R H V and Lee, C H (1992). The physiological basis for genetic improvement of oil palm in Malaysia. Euphytica, 60(3): 179-184.

Corley, R (2005). Illegitimacy in oil palm breeding. J. Oil Palm Res. Vol. 17: 64-69.

Corley, R H V and Tinker, P B (2008). The Oil Palm. John Wiley \& Sons. p. 47.

Davidson, L (1993). Management for efficient cost effective and productive oil palm plantations. Proc. of the 1991 PORIM International Palm Oil Conference - Agriculture (Basiron, Y et al., eds.). MPOB, Bangi. p. 153-167.

Donough, C R; Ng, M and Lai, C (1993). Pamol's approach to quality control in controlled pollination for DxP seed production. Planter, 69: 163-175.

Fauconnier, H (1948). The Soul of Malaya. Penguin, London. 191 pp.

Foulkes, W D; Knoppers, B M and Turnbull, C (2016). Population genetic testing for cancer susceptibility: Founder mutations to genomes. Nature Reviews Clinical Oncology, 13(1): 41 pp.

Hama-Ali, E O; Alwee, S S R S; Tan, S G; Panandam, J M; Ling, H C; Namasivayam, P and Peng, H B (2015). Illegitimacy and sibship assignments in oil palm (Elaeis guineensis Jacq.) half-sib families using single locus DNA microsatellite markers. Molecular Biology Reports, 42(5): 917-925.

Hunger, F T W (1924). De Oliepalm (Elaeis guineensis): Historisch onderzoek over den oliepalm in Nederlandisch-Indie. N V Boekhandel en Drukkerij voorheen E J Brill, Leiden.

Issa, I A and Noureddine, M (2017). Colorectal cancer screening: An updated review of the available options. World J. Gastroenterology, 23(28): 5086.

Ivancic, H and Koh, L P (2016). Evolution of sustainable palm oil policy in Southeast Asia. Cogent Environmental Science, 2(1): 1195032.

Jagoe, RB (1952). Deli oil palms and early introductions of Elaeis guineensis to Malaya. Malay Agri. J., 35: 4-11.

James, C (2014). Preview: Global Status of Commercialized Biotech/GM Crops, ISAAA Brief No. 49. International Service for the Acquisition of Agro-biotech Application, Ithaca, New York.

Kamil, N N and Omar, S F (2017). The impact of El Niño and La Niña on Malaysian palm oil industry. Oil Palm Bulletin No. 74: 1-6. 
Kelanaputra, E S; Nelson, S P; Setiawati, U; Sitepu, B; Nur, F; Forster, B P and Purba, A R (2018). Seed Production in Oil Palm: A Manual. CABI.

Krieger, N; Nabavi, S; Waterman, P D; Achacoso, N S; Acton, L; Schnitt, S J and Habel, L A (2018). Feasibility of analyzing DNA copy number variation in breast cancer tumor specimens from 1950-2010: How old is too old? Cancer Causes and Control, 29(3): 305-314.

Kushairi, A; Singh, R and Ong-Abdullah, M (2017). The oil palm industry in Malaysia: Thriving with transformative technologies. J. Oil Palm Res. Vol. 29(4): 431-439.

Kushairi, A; Ong-Abdullah, M; Nambiappan, B; Hishamuddin, E; Bidin, M N I Z; Ghazali, R; Subramaniam, V; Sundram, S and Parveez, G K A (2019). Oil palm economic performance in Malaysia and R\&D progress in 2018. J. Oil Palm Res. Vol. 31: 65-194.

Lakey, N D; Ordway, J M; Jiang, N; Smith, S W; Favello, A; Ooi, L C L; Singh, R; Nookiah, R; Low, E T L; Ong-Abdullah, M and Sambanthamurthi, R (2017). Increasing oil palm industry profit, Malaysian gross national income and government tax revenue with breakthrough DNA tests. Planter, 93(1093): 273-279.

Low, E T L; Singh, R; Ong-Abdullah, M; Lakey, N D; Ordway, J M; Smith, S W; Ooi, L C L; Rajanaidu, N; Sambanthamurthi, R; Martienssen, R A and Manaf, M A A (2018). Oil palm genome technology breakthroughs for enhance sustainability of the oil palm industry. In the $14^{\text {th }}$ International Symposium on Biocatalysis and Agricultural Biotechnology. 22-24 October 2018. Kuala Lumpur, Malaysia. 103 pp.

Low, E T L; Singh, R; Rajanaidu, N; Ong-Abdullah, M; Ooi, L C L; Lakey, N D; Smith, S W; Ordway, J M and Sambanthamurthi, R (2016). New frontiers for the oil palm industry through genome technology. Planter, 92(1087): 701-710.

Lusser, M; Parisi, C; Plan, D and Rodríguez-Cerezo, E (2012). Deployment of new biotechnologies in plant breeding. Nature Biotechnology, 30(3): 231239.

Molparia, B; Oliveira, G; Wagner, J L; Spencer, E G and Torkamani, A (2018). A feasibility study of colorectal cancer diagnosis via circulating tumor DNA derived CNV detection. PLOS ONE, 13(5): p.e0196826.

MPOB (2017). Malaysian Palm Oil Statistics 2016. $36^{\text {th }}$ edition. MPOB, Bangi.
MPOB (2018). Malaysian Palm Oil Statistics 2017. 37 th edition. MPOB, Bangi.

MPOB (2019). Malaysian Palm Oil Statistics 2018. $38^{\text {th }}$ edition. MPOB, Bangi.

MPOB (2020). Malaysian Palm Oil Statistics 2019. $39^{\text {th }}$ edition. MPOB, Bangi.

Murphy, D J (2007). Future prospects for oil palm in the $21^{\text {st }}$ century: Biological and related challenges. European J. Lipid Science and Technology, 109(4): 296-306.

Murphy, D J (2014). The future of oil palm as a major global crop: Opportunities and challenges. J. Oil Palm Res. Vol. 26(1): 1-24.

Nambiappan, B; Ismail, A; Hashim, N; Ismail, N; Nazrima, S; Idris, N A N; Omar, N; Saleh, K M; Hassan, N A M and Kushairi, A (2018). Malaysia: 100 years of resilient palm oil economic performance. J. Oil Palm Res. Vol. 30(1): 13-25.

Oberthür, T; Donough, C R; Indrasuara, K; Dolong, T and Abdurrohim, $G$ (2012). Successful intensification of oil palm plantations with best management practices: Impacts on fresh fruit bunch and oil yield. Proc. Int'l Planters' Conference. p. 67-102.

Ornelas, K C (2000). The Cambridge World History of Food (Vol. 2). Cambridge University Press.

Ooi, L C L; Low, E T L; Abdullah, M O; Nookiah, R; Ting, N C; Nagappan, J; Manaf, M A; Chan, K L; Halim, M A; Azizi, N and Omar, W (2016). Nontenera contamination and the economic impact of SHELL genetic testing in the Malaysian independent oil palm industry. Frontiers in Plant Science, 7: 771.

Parveez, G K A; Rasid, O A; Masani, M Y A and Sambanthamurthi, R (2015). Biotechnology of oil palm: Strategies towards manipulation of lipid content and composition. Plant Cell Reports, 34(4): 533-543.

Rajanaidu, N and Jalani, B S (1994). Influence of planting material on oil extraction ratio (OER). National Seminar on Palm Oil Extraction Rate: Problem's and Issues (Ariffin, D and Jalani, B S eds.). 21-22 December 1994. PORIM, Bangi. p. 53-57.

Rao, V (2016). Oil palm shell gene and DxP purity in independent plantings. The Planter, 92(1086): 663-664.

Rao, V; Jalani, B S and Rajanaidu, N (1994). Effect of dura contamination on oil extraction rate (OER). National Seminar on Palm Oil Extraction Rate: Problems and Issues (Ariffin, D and Jalani, B S eds.). 21-22 December 1994. PORIM, Bangi. p. 58-60. 
Rao, V and Chang, K C (2014). Oil Palm Seed Production: Field and Laboratory Manual. MPOB, Bangi. 88 pp.

Rao, V and Chang, K C (2018). MS 157: An evolving story. The Planter, 94(1109): 491-502.

Reyes, P A; Ochoa, J C; Montoya, C; Daza, E; Ayala, I M and Romero, H M (2015). Development and validation of a bi-directional allele-specific PCR tool for differentiation in nurseries of dura, tenera and pisifera oil palms. Agronomía Colombiana, 33(1): $5-10$.

Sambanthamurthi, R; Singh, R; Kadir, A P G; Abdullah, M O and Kushairi, A (2009). Opportunities for the oil palm via breeding and biotechnology. Breeding Plantation Tree Crops: Tropical Species. Springer, New York. p. 377-421.

Sandin, P and Moula, P (2015). Modern biotechnology, agriculture and ethics. J. Agricultural and Environmental Ethics, 28(5): 803-806.

Shukoor, M; Shuhada, N; Tamrin, M; Bahri, S; Guan, N Y; Nata, M S and Hazwani, D (2018). Development of new hard hat dimensions using user-centered design approach among oil palm harvesters. Work, 60(1): 129-134.

Singh, R; Low, E T L; Ooi, L C L; Ong-Abdullah, M; Ting, N C; Nagappan, J; Nookiah, R; Amiruddin, M D; Rosli, R; Manaf, M A A and Chan, K L (2013a). The oil palm SHELL gene controls oil yield and encodes a homologue of SEEDSTICK. Nature, 500(7462): 340-344.

Singh, R; Ong-Abdullah, M; Low, E T L; Manaf, M A A; Rosli, R; Nookiah, R; Ooi, L C L; Ooi, S E; Chan, K L; Halim, M A and Azizi, N (2013b). Oil palm genome sequence reveals divergence of interfertile species in old and new worlds. Nature, 500(7462): 335-339.

Singh, R; Low, E T L; Ooi, L C L; Ong-Abdullah, M; Ting, N C; Nookiah, R; Ithnin, M; Marjuni, M; Mustaffa, S; Yaakub, Z; Amiruddin, M D; Manaf, M A A; Chan, K L; Halim, M A A; Sanusi, N S N M; Lakey, N; Sachdeva, M; Bacher, B; Garner, P A; MacDonald, J D; Smith, S W; Wischmeyer, C; Budiman, M A; Beil, M; Stroff, C; Reed, J; Van Brunt, A; Berg, H; Ordway, J M and Sambanthamurthi, $R$ (2020). Variation for heterodimerization and nuclear localization among known and novel oil palm SHELL alleles. New Phytologist, 226(2): 426440 .

Slack, N; Chambers, S and Johnston, R (2010). Operations Management. Pearson Education. p. 270.
Sniezko, R A and Koch, J (2017). Breeding trees resistant to insects and diseases: Putting theory into application. Biological Invasions, 19(11): 33773400 .

Stevanato, P; Trebbi, D; Panella, L; Richardson, K; Broccanello, C; Pakish, L; Fenwick, A L and Saccomani, M (2015). Identification and validation of a SNP marker linked to the gene HsBvm-1 for nematode resistance in sugar beet. Plant Molecular Biology Reporter, 33(3): 474-479.

Sutton, K (1989). Malaysia's FELDA land settlement model in time and space. Geoforum, 20(3): 339-354.

Takata, M (2008). The Development and Current Issues of the Malaysian Palm Oil Industry Dissertation 74, 29. Department of Social and Environmental Studies. Fukuoka Institute of Technology, Japan.

Tomlinson, I (2013). Doubling food production to feed the 9 billion: A critical perspective on a key discourse of food security in the United Kingdom. J. Rural Studies, 29: 81-90.

Tzachor, A (2019). The future of feed: Integrating technologies to decouple feed production from environmental impacts. Industrial Biotechnology, 15(2): 52-62.

Urnov, F D; Ronald, P C and Carroll, D (2018). A call for science-based review of the European court's decision on gene-edited crops. Nature Biotechnology, 36(9): 800.

Vanderzande, S; Piaskowski, J L; Luo, F; EdgeGarza, D; Klipfel, J; Schaller, A; Martin, S and Peace, C (2018). Crossing the finish line: How to develop diagnostic DNA tests as breeding tools after QTL discovery. J. Hortic, 5(228): 2376-0354.

Van Gelder, J W (2004). Greasy Palms: European Buyers of Indonesian Palm Oil. Friends of the Earth, London.

Van Nocker, S and Gardiner, S E (2014). Breeding better cultivars, faster: Applications of new technologies for the rapid deployment of superior horticultural tree crops. Horticulture Research, 1(1): $1-8$.

Wahid, M B and Simeh, M A (2009). Issues related to production cost of palm oil in Malaysia. Oil Palm Industry Economic J., 9(2): 1-12.

Wannemuehler, S D; Luby, J J; Yue, C; Bedford, D S; Gallardo, R K and McCracken, V A (2019). A cost- 
benefit analysis of DNA informed apple breeding. HortScience, 54(11): 1998-2004.

Wannemuehler, S D; Yue, C; Hoashi-Erhardt, W K; Gallardo, R K and McCracken, V (2020). Costeffectiveness analysis of a strawberry breeding program incorporating DNA-informed technology. HortTechnology, 30(3): 365-371.

Zimmer, Y (2016). Competitiveness of rapeseed, soybeans and palm oil. J. Oilseed Brassica, 1(2): 8490. 